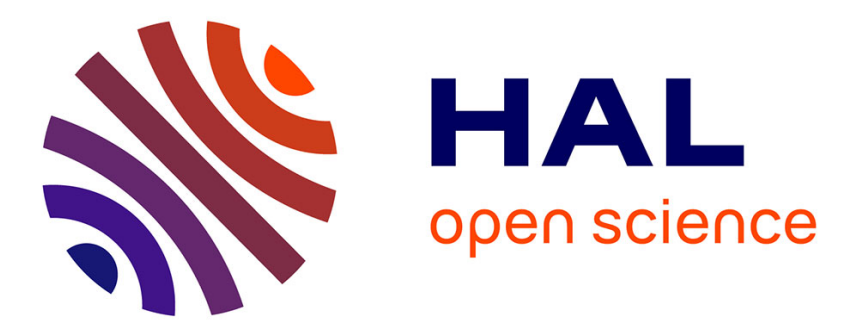

\title{
Small unilamellar liposomes as a membrane model for cell inactivation by cold atmospheric plasma treatment
}

S Maheux, G Frache, J S Thomann, Franck Clement, C Penny, T. Belmonte, D Duday

\section{- To cite this version:}

S Maheux, G Frache, J S Thomann, Franck Clement, C Penny, et al.. Small unilamellar liposomes as a membrane model for cell inactivation by cold atmospheric plasma treatment. Journal of Physics D: Applied Physics, 2016, 49 (34), pp.344001. 10.1088/0022-3727/49/34/344001 . hal-02113590

\author{
HAL Id: hal-02113590 \\ https://hal.science/hal-02113590
}

Submitted on 10 May 2019

HAL is a multi-disciplinary open access archive for the deposit and dissemination of scientific research documents, whether they are published or not. The documents may come from teaching and research institutions in France or abroad, or from public or private research centers.
L'archive ouverte pluridisciplinaire $\mathbf{H A L}$, est destinée au dépôt et à la diffusion de documents scientifiques de niveau recherche, publiés ou non, émanant des établissements d'enseignement et de recherche français ou étrangers, des laboratoires publics ou privés. 


\title{
Small unilamellar liposomes as membrane model for cell inactivation by cold atmospheric plasma treatment
}

\author{
S Maheux ${ }^{1,3}$, G Frache ${ }^{1}$, J S Thomann'1, F. Clément ${ }^{2}$, C Penny ${ }^{1}$, T Belmonte ${ }^{3}$, D Duday ${ }^{1}$ \\ ${ }^{1}$ Luxembourg Institute of Science and Technology (LIST), 5 Avenue des Hauts Fourneaux, L-4362 \\ Esch/Alzette, Luxembourg
}

${ }^{2}$ Université de Pau UPPA - IPREM UMR 5254-LCABIE, Plasmas and Applications, 2 Avenue du Président Angot, F-64000 Pau, France

${ }^{3}$ Université de Lorraine - Institut Jean Lamour UMR CNRS 7198, Chemistry and Physics of Solids and Surfaces, CS 14234, F-54042 Nancy Cedex, France

Email: david.duday@list.lu

\begin{abstract}
Cold atmospheric plasma is thought to be a promising tool for numerous biomedical applications due to its ability to generate a large diversity of reactive species in a controlled way. In some cases, it can also generate pulsed electric fields at the zone of treatment, which can induce processes such as electroporation in cell membranes. However, the interaction of these reactive species and the pulse electric field with cells in a physiological medium is very complex and still need a better understanding in order to be useful for future applications. A way to reach this goal is to work with model cell membranes such as liposomes, with the simplest physiological liquid and in a controlled atmosphere in order to limit the number of parallel reactions and processes. In this work, where this approach has been chosen, 1,2Dioleoyl-sn-glycero-3-phosphocholine (DOPC) small unilamellar vesicles (SUV) has been synthesized in phosphate buffered aqueous solution and this solution has been treated by a nanosecond pulsed plasma jet under a pure nitrogen atmosphere. Only the composition of the plasma gas has been changed in order to generate different cocktails of reactive species. After the quantification of the main plasma reactive species in the PBS solution, structural, surface charge state, and chemical modifications generated on the plasma treated liposomes, due to the interaction with the plasma reactive species, has been carefully characterized. These results allow going further in the understanding of the effect of plasma reactive species on model cell membranes in physiological liquids. Permeation through the liposomal membrane and reaction of plasma reactive species with molecules encapsulated inside the liposomes has also been evaluated. New processes of degradation are finally presented and discussed, which come from the specific conditions of plasma treatment under pure nitrogen atmosphere.
\end{abstract}

\section{Introduction}

Disinfection of liquids or wet surfaces by means of cold atmospheric plasma (CAP) treatment is seen as a promising field and market [1,2]. In particular, CAP treatments are envisaged for the disinfection or treatment of biological media due to their biocompatible working conditions i.e. ambient pressure and ambient temperature, and the use of low quantities of biocompatible gases [3-5]. For therapeutic applications, the behavior of human or plant cells can also be affected or controlled by their interaction with plasma reactive species, which are often naturally present in living organisms. Therefore, numerous teams have studied the interaction of CAP with biological samples and have investigated mechanisms which could explain the antibacterial properties of plasma treatments on solutions or gels containing bacteria or other living cells. The disinfection or therapeutic efficiency of the CAP processes was shown to be due to the generation of several reactive oxygen and nitrogen species (RONS): hydrogen peroxide, peroxynitrite, ozone or hydroxyl and perhydroxyl radicals among others, with the potential contribution of plasma-issued (V)UV photons [6-12] and pulsed electric fields. Recently, hypochlorite ions and chloramine were shown to play a role in the disinfection process at neutral $\mathrm{pH}$ when a nanosecond pulsed cold atmospheric microplasma was in contact with a phosphate buffered saline solution under a $\mathrm{N}_{2}$ atmosphere [13]. A way to go further into the understanding of plasma disinfection processes is to plasma treat suspensions of model cells as it was already made in [14]. It is well known that unsaturated phospholipids such as DOPC are more present in eukaryotic 
cells membrane compare to bacteria membrane more rich in saturated lipids. Unsaturated lipids are also more sensitive to oxidation promoted by UV or RONS species especially compare to saturated phospholipids such as DPPC. However, the presence of a high concentration of cholesterol in eukaryotic cells drastically decrease the damage induced by DOPC oxidation. Even if bacteria have less amount of unsaturated lipids, oxidation of them will results into much higher impact than eukaryote cells due to the relative low concentration of cholesterol in bacteria membrane. Investigations focusing on the interaction between RONS generated by CAP in liquids and DOPC liposomes could also help to better understand the selectivity of CAP treatment during disinfection processes promoted by CAP. A first study using this approach has shown that CAP can induce a disruption of liposomes and the fusion of small liposomes into bigger ones [14]. However the origin of these liposome modifications are still not known and can be due to physical effects (temperature, electric field) or/and chemical effects such an alteration of the phospholipid chemical structure by reactive species generated in solution. In this work, we have investigated how CAP can chemically and structurally impact the DOPC phospholipids bilayers using SUV vesicles loaded with carboxyfluorescein molecules as a model of cell. Liposome stability under CAP processes has been investigated using Dynamic Light Scattering and fluorescence spectroscopy. Chemical modification on DOPC induced by CAP has been characterized using MALDI-Orbitrap mass spectrometry methods. Impact of CAP processes has been compared with the effect of chemical compounds just added in liposome suspensions in the same conditions used for the treatment of bacteria in our previous work [13] with the main difference being the addition of $5 \mathrm{mM}$ of $\mathrm{Mg}^{2+}$ to stabilize the liposomes [15]. Plasma CAP treatment

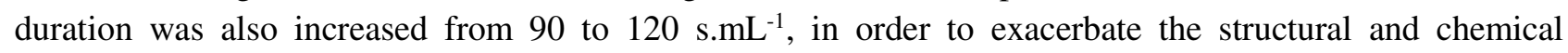
alteration of the DOPC liposomes.

\section{Methods}

The following chemicals were purchased and used without further purification: 1,2-dioleoyl-sn-glycero-3phosphocholine $2.5 \mathrm{mg} \cdot \mathrm{mL}^{-1}$ in chloroform (Avanti Polar Lipids), 5(6)-carboxyfluorescein (Sigma-Aldrich). During the treatment of liposome suspensions, a controlled $\mathrm{N}_{2}$ atmosphere was generated all around the microplasma jet to favor the generation of reactive nitrogen species as shown in Figure 1. Liposomes were prepared and treated in a phosphate buffered saline (PBS) solution also containing $5 \mathrm{mM}$ of $\mathrm{MgCl}_{2}$. Interaction between custom-built CAP, with a plasma reactor made at UPPA, in a controlled nitrogen atmosphere or chemicals mimicking reactive species produced by CAP, PBS solutions and liposomes are presented and discussed. $\mathrm{He}, \mathrm{He}+0.50 \% \mathrm{~N}_{2}$ and $\mathrm{He}+0.50 \% \mathrm{O}_{2}$ process gas are used here because these gas mixtures were shown to present very different bacterial inactivation efficiencies [13]. Effect of hypochlorite $\left(\mathrm{ClO}^{-}\right)$- in this paper, hypochlorite will refer to both hypochlorite ion and its acidic counterpart hypochlorous acid, hydrogen peroxide $\left(\mathrm{H}_{2} \mathrm{O}_{2}\right)$, nitrites $\left(\mathrm{NO}_{2}{ }^{-}\right)$, peroxynitrites $\left(\mathrm{ONOO}^{-}\right)$, monochloramine $\left(\mathrm{NH}_{2} \mathrm{Cl}\right)$, ammonium $\left(\mathrm{NH}_{4}{ }^{+}\right)$and nitryl chloride $\left(\mathrm{NO}_{2} \mathrm{Cl}\right)$ reactive species on the liposome chemical structure were also assessed independently and compared to the CAP treatments in order to better understand the inactivation mechanism discussed in our previous work [13] and to better predict plasma reactive species interaction with eukaryotic cells for future biomedical applications.

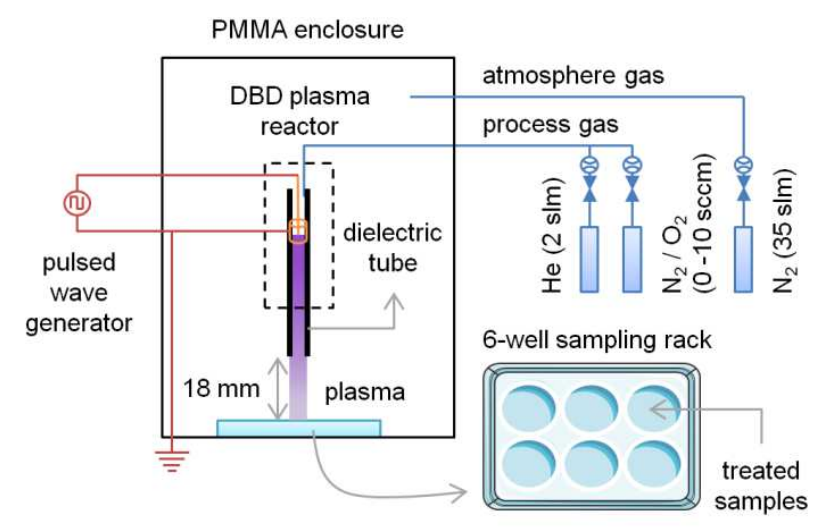




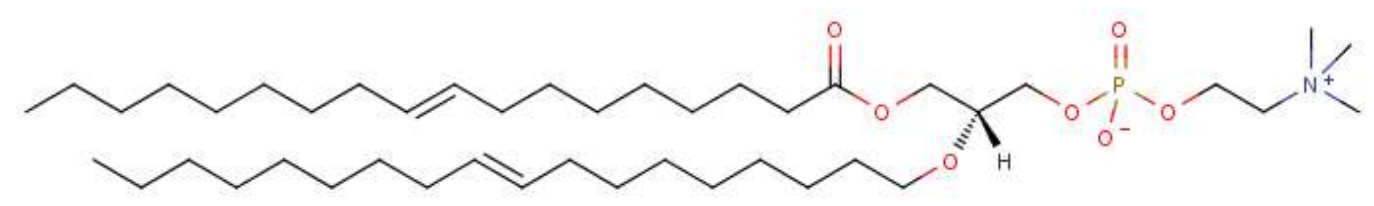

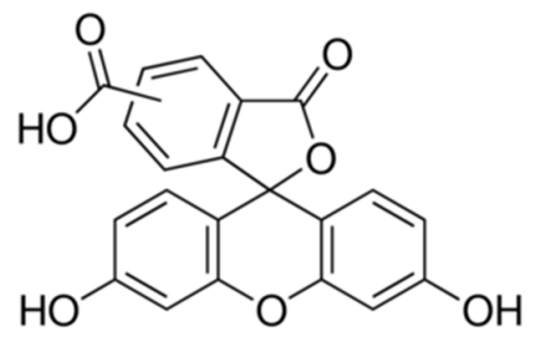

Figure 2: Chemical structures of 1,2-dioleoyl-sn-glycero-3-phosphocholine and (5)6-carboxyfluorescein

The experimental setup we used for plasma treatments is depicted in figure 1. It has already been described in previous publications [13, 16]. Briefly, the dielectric barrier discharge (DBD) plasma reactor consisted of a tungsten filament powered by a pulsed HV and inserted in an alumina dielectric tube. A metallic grounded ring was enclosed outside the tube. Process gas, fed into the reactor through MKS mass flow controllers, was either $\mathrm{He}$ at a 2 standard litres per minute $(\mathrm{slm})$ flow rate, $\mathrm{He}(2 \mathrm{slm}) / \mathrm{N}_{2}$ (10 standard cubic centime per minute $(\mathrm{sccm}))$ mixture or $\mathrm{He}(2 \mathrm{slm}) / \mathrm{O}_{2}(10 \mathrm{sccm})$ mixture. Plasma was generated by applying a $5 \mathrm{kV}, 15$ $\mathrm{kHz}, 1.5 \%$ duty cycle, positive nanosecond pulsed wave potential between the two electrodes. Control over the atmosphere composition during plasma treatments was obtained by providing a constant $\mathrm{N}_{2}$ flow ( $35 \mathrm{slm}$ ) inside a poly(methyl methacrylate) enclosure surrounding the DBD plasma reactor without affecting the plasma treatment zone, thus creating a low overpressure in the chamber. The DBD reactor sat on a 3-axis robot to ensure reproducible plasma treatments. Liquid samples to be plasma-treated were poured in a 6-well sampling rack $(5 \mathrm{~mL}$ per well) and placed in the enclosure, below the DBD plasma reactor. The vertical distance between the tip of the alumina dielectric tube and the liquid interface was kept constant at $18 \mathrm{~mm}$.

All liposome suspensions were prepared from 1,2-dioleoyl-sn-glycero-3-phosphocholine (DOPC) commercial stock solution in chloroform $\left(2.5 \mathrm{mg} \cdot \mathrm{mL}^{-1}\right) .786 \mu \mathrm{L}$ of this stock was transferred into 4-mL Wheaton sample vial. By tilting and rotating regularly the vial under constant $\mathrm{N}_{2}$ gas flow, chloroform solvent evaporated to give a white DOPC film on the vial's wall. $2.5 \mathrm{~mL}$ of degassed PBS buffer - with or without (5)6-carboxyfluorescein $50 \mathrm{mM}$ - and a stirring magnet were then added. The solution was stirred twice for $30 \mathrm{~min}$ at $1000 \mathrm{rpm}$, with a $60 \mathrm{~min}$ break at $4^{\circ} \mathrm{C}$ in between. Thereafter, the vial was submitted to a 30 -min sonication. The solution is then filtered through a $200-\mathrm{nm}$ polycarbonate filter (one pass) before extrusion through a $100-\mathrm{nm}$ polycarbonate filter (9 passes). The extruded suspension finally undergoes two filtration steps on PD-10 desalting columns filled with Sephadex G25 medium (GE Healthcare) to remove non-encapsulated (5)6-carboxyfluorescein molecules. Before plasma or wet chemistry treatments, the DOPC liposome suspension is diluted 20 times in PBS $+\mathrm{Mg}^{2+} 5 \mathrm{mM}$ to reach the desired DOPC concentration of 50 $\mu \mathrm{M}$.

For chemical treatments, $2 \mathrm{~mL}$ of liquid samples in 12-well sampling rack were used. Measurements were carried out 4 hours after adding the chemical compounds matching the reactive species generated by CAP in solution, in order to ensure a full reaction between phospholipids and reactive species.

Concentration of main reactive species in PBS solutions treated by CAP were determined by photometric rapid Spectroquant ${ }^{\circledR}$ tests from Merck (1.18789 test for $\mathrm{H}_{2} \mathrm{O}_{2}, 1.14776$ test for $\mathrm{NO}_{2}{ }^{-}, 1.14773$ test for $\mathrm{NO}_{3}{ }^{-}$ 1.14752 test for $\mathrm{NH}_{4}{ }^{+}$and 1.00599 test for $\mathrm{HClO}$ and $\mathrm{NH}_{2} \mathrm{Cl}$ ). When necessary, plasma treated PBS solutions 
were diluted to avoid interference effects with other reactive species. When the dilution approach was not possible, a chemical compound has been added before the colorimetric test to eliminate the reactive species generating interferences. Therefore, for some measurements, catalase and sulfamic acid have been added to eliminate $\mathrm{H}_{2} \mathrm{O}_{2}$ and $\mathrm{NO}_{2}^{-}$, respectively.

Size distribution and zeta potential of liposomes were respectively measured by dynamic light scattering and laser Doppler electrophoresis, before and after treatment, with a Zetasizer Nano ZS (Malvern Instruments). Samples were poured in DTS1070 disposable cells without further preparation, measurements were performed at $25 \pm 1^{\circ} \mathrm{C}$.

Fluorescence intensity measurements of 5(6)carboxyfluorescein-loaded samples were performed on an Infinite M1000 Pro UV/vis spectrophotometer (Tecan), with $200 \mu \mathrm{L}$ of each sample poured in a 96-well sampling rack. In this work, fluorescence intensity of a sample was defined as the area under the curve of fluorescence emission between 500 and $650 \mathrm{~nm}$ when this sample is excited at a wavelength of $490 \mathrm{~nm}$; its value was normalized against a reference untreated sample.

Some treated liposome solutions were analyzed with atmospheric pressure matrix-assisted laser desorption/ionization-Orbitrap mass spectrometry (AP-MALDI-Orbitrap). For analysis, treated samples were diluted 10 times in a methanol / water mixture (50/50, volume/volume). $1 \mu \mathrm{L}$ droplets of these diluted samples were laid down on a gold-plated steel plate. After evaporation of solvents, remaining liposomes and salts from the droplets were rinced twice with $1 \mu \mathrm{L}$ of milliQ water to desalt as much as possible the samples. Then, dried desalted liposome samples were mixed to $1 \mu \mathrm{L}$ of a matrix, made of 2,5dihydroxybenzoic acid $15 \mathrm{mg} \cdot \mathrm{mL}^{-1}$ in methanol / trifluoroacetic acid mixture (50/50, volume/volume), to protect DOPC lipid from excessive photon irradiation and favour its ionization during AP-MALDI analysis. All measurements were made in triplicate.

\section{Results}

Under constant $\mathrm{N}_{2}$ atmosphere, we performed a set of $120 \mathrm{~s} \cdot \mathrm{mL}^{-1}$ plasma treatments on PBS $+\mathrm{Mg}^{2+} 5 \mathrm{mM}$ solution at neutral $\mathrm{pH}$ and ambient temperature. Colorimetric tests on the plasma treated solutions allowed for the evaluation of their concentration after plasma treatment, as shown on Table 1.

\begin{tabular}{|c|c|c|c|}
\hline & $\begin{array}{l}\text { Conc. }(\mu \mathrm{M}) \\
\mathrm{He}+\mathrm{O}_{2} \text { plasma }\end{array}$ & $\begin{array}{l}\text { Conc. }(\mu \mathrm{M}) \\
\text { He plasma }\end{array}$ & $\begin{array}{l}\text { Conc. }(\mu \mathrm{M}) \\
\mathrm{He}+\mathrm{N}_{2} \text { plasma }\end{array}$ \\
\hline $\mathrm{H}_{2} \mathrm{O}_{2}$ & $150 \pm 50$ & $550 \pm 50$ & $350 \pm 50$ \\
\hline $\mathrm{NO}_{2}^{-}$ & $500 \pm 50$ & $2000 \pm 100$ & $4800 \pm 200$ \\
\hline $\mathrm{NO}_{3}{ }^{-}$ & $\begin{array}{lr}\text { not measured, conc. }< & 1000 \\
\text { expected (plasma } & \text { jet } \\
\text { quenching due to ROS) } & \end{array}$ & $1400 \pm 100$ & $2000 \pm 100$ \\
\hline $\mathrm{NH}_{4}{ }^{+}$ & not detected & not detected & $65 \pm 3$ \\
\hline $\mathrm{NH}_{2} \mathrm{Cl}$ & not detected & not detected & $8 \pm 2$ \\
\hline $\mathrm{HClO}$ & $\begin{array}{l}\text { not measured, conc. }<2 \\
\text { expected (plasma } \\
\text { quenching due to ROS) }\end{array}$ & $5 \pm 2$ & $5 \pm 2$ \\
\hline
\end{tabular}

Table 1: Evaluation of the quantity of reactive species generated in $\mathrm{PBS}+\mathrm{Mg}^{2+}$ solutions at neutral $\mathrm{pH}$ after 120 s.mL ${ }^{-1}$ plasma treatments 
For all the plasma treatments, a low $\mathrm{H}_{2} \mathrm{O}_{2} / \mathrm{NO}_{\mathrm{x}}$ ratio was observed due to the pure nitrogen atmosphere used. Due to the plasma jet quenching induced by the highest density of reactive oxygen species generated in the discharge zone, the quantity of reactive species generated in PBS solution by $\mathrm{He}+0.50 \% \mathrm{O}_{2}$ plasma is much lower compared with the two other plasma treatments (Table 1). Except for $\mathrm{HClO}$ and $\mathrm{H}_{2} \mathrm{O}_{2}, \mathrm{He}$ plasma treatments generated reactive species in lower amounts compared with $\mathrm{He}+0.50 \% \mathrm{~N}_{2}$ plasma ones. For $\mathrm{He}$ $+0.50 \% \mathrm{~N}_{2}$ plasma treatments, much higher concentrations in $\mathrm{NO}_{\mathrm{x}}$ and the generation of additional reactive species (i.e. $\mathrm{NH}_{4}{ }^{+}$and $\mathrm{NH}_{2} \mathrm{Cl}$ ) were detected.

Then, we performed a set of $120 \mathrm{~s} \cdot \mathrm{mL}^{-1}$ plasma treatments on 100-nm small unilamellar DOPC vesicles (also called liposomes), containing $50 \mathrm{mM}$ of 5(6)-carboxyfluorescein, suspended in PBS $+\mathrm{Mg}^{2+} 5 \mathrm{mM}$. Dynamic light scattering measurements of these samples allowed for the determination of their size distribution profile, before and after plasma treatment, as shown on Figure 3.

One wide peak centred on $1000 \mathrm{~nm}$, appeared after $\mathrm{He}+0.50 \% \mathrm{~N}_{2} 120 \mathrm{~s} \cdot \mathrm{mL}^{-1}$ plasma treatment (Figure 3, blue line), while the initial peak centred on $100 \mathrm{~nm}$ decreased. The liposomes coalescence phenomenon observed under $\mathrm{He}+0.50 \% \mathrm{~N}_{2}$ plasma treatment would explain the peak centred on $1000 \mathrm{~nm}$ and the decrease of the one centred on $100 \mathrm{~nm}$ (liposomes before treatment). The similar profile of the peak centred at $100 \mathrm{~nm}$ for the EtOH chemical treatment (10\% addition (volume / volume) to the liposome suspension) and the one of $\mathrm{He}+0.50 \% \mathrm{~N}_{2} 120 \mathrm{~s} \cdot \mathrm{mL}^{-1}$ plasma treatment indicates that liposomes leaked a significant part of their 5(6)-carboxyfluorescein molecules. Indeed, the addition of ethanol is known to increase the permeability of liposomes to hydrophilic molecules and in our case it favours the disruption of the small unilamellar vesicles (SUV) and the delivery of the fluorescent molecules [17,18].

He 120 s.mL ${ }^{-1}$ plasma treatments (Figure 3, black line) result in a gentler decrease of the peak centred on 100 $\mathrm{nm}$ indicating that the major part of the SUVs do not break and do not leak. The peak centred on $500 \mathrm{~nm}$ is thought to be mainly due to of the agglomeration of several SUVs because no significant leak of fluoresecent molecules is detected (i.e. peak at $100 \mathrm{~nm}$ similar to non-treated reference one). 100-nm DOPC liposomes form 500-nm liposomal clusters through weak interaction, without rupture of liposome and leakage of the fluorescent dye. $\mathrm{He}+0.50 \% \mathrm{O}_{2} 120 \mathrm{~s} . \mathrm{mL}^{-1}$ plasma treatment (Figure 3, red line) did not change significantly the size distribution profile of the DOPC liposomes. No structural degradation of liposomes is then generated with these milder plasma treatments. 


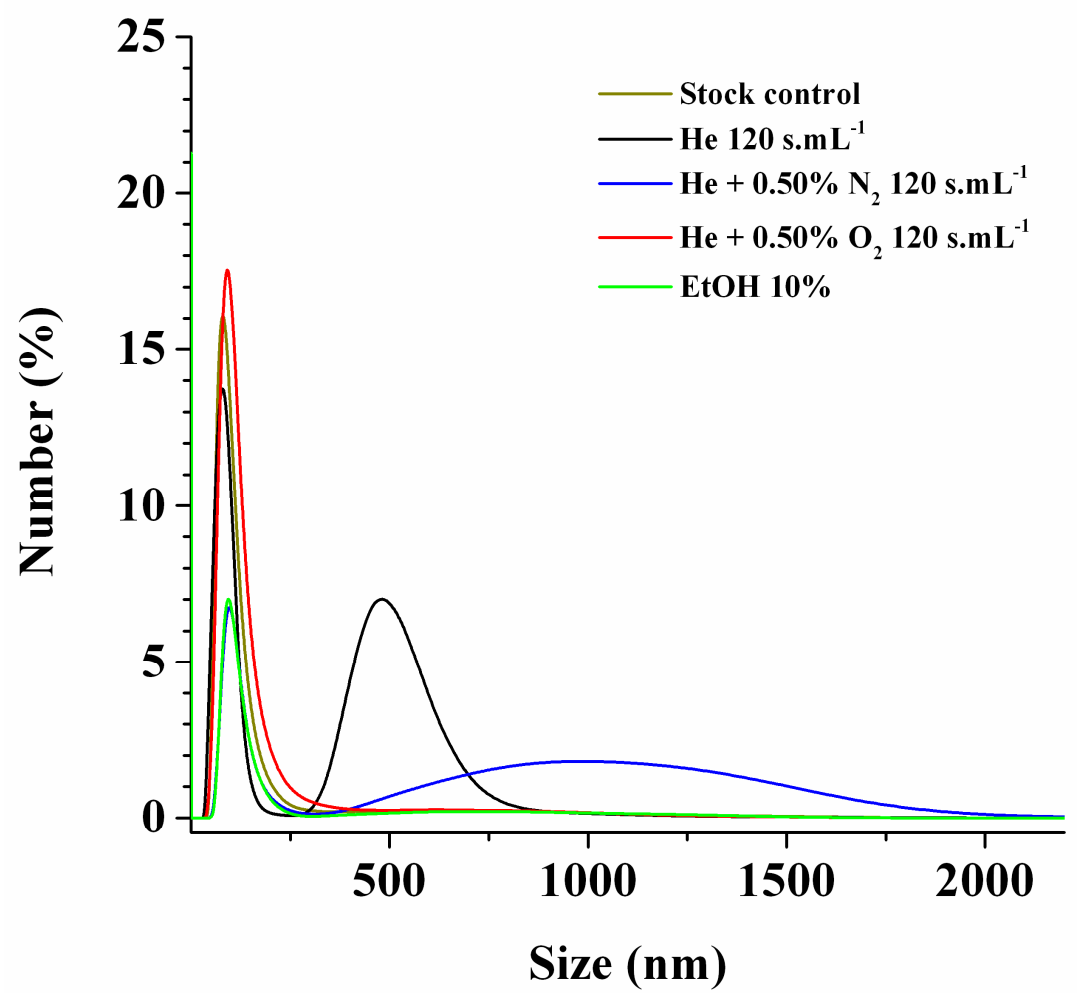

Figure 3: Size distribution profile of DOPC liposomes, encapsulating (5)6-carboxyfluorescein 50 mM, in PBS +

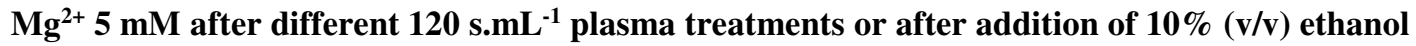

The zeta potential of DOPC liposomes was also determined from their electrophoretic mobility measured on a Malvern Zetasizer Nano ZS (Figure 4). While untreated DOPC liposomes in PBS showed an almost neutral zeta potential $(-1.0 \pm 2.6 \mathrm{mV})$, zeta potentials after $\mathrm{He} 120 \mathrm{~s} \cdot \mathrm{mL}^{-1}$ and $\mathrm{He}+0.50 \% \mathrm{~N}_{2} 120 \mathrm{~s} . \mathrm{mL}^{-1}$ plasma treatments both decreased to more negative values (respectively $-11.8 \pm 4.1 \mathrm{mV}$ and $-21.4 \pm 4.4 \mathrm{mV}$ ). The

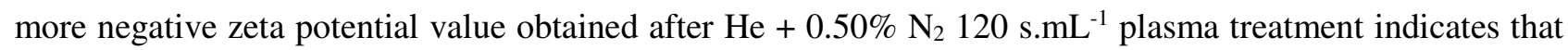
the surface of the treated liposomes is more negatively charged due to a larger number of chemical modifications generated on the phospholipids.

The treatment of DOPC liposomes by $\mathrm{He}+0.50 \% \mathrm{O}_{2} 120 \mathrm{~s} \cdot \mathrm{mL}^{-1}$ plasma and ethanol $10 \%$ did not modify significantly the zeta potential $(-3.0 \pm 1.4 \mathrm{mV})$. It means that no significant chemical modifications are generated on the phospholipids for these two treatments. 


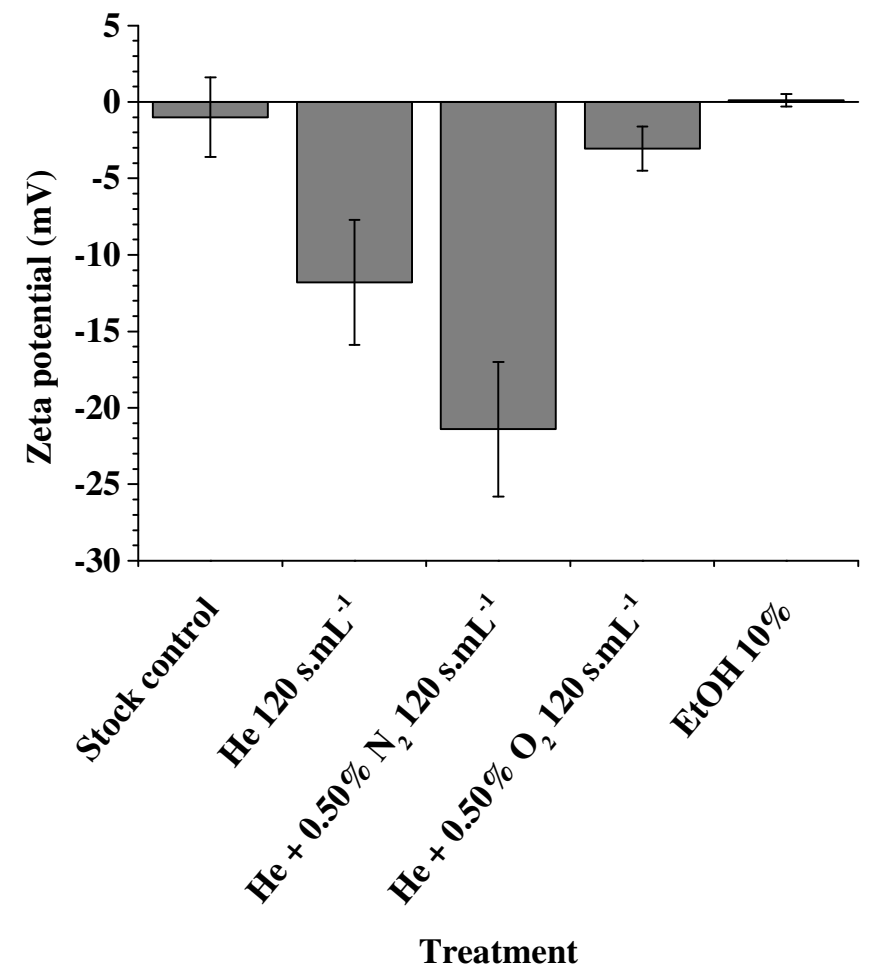

Figure 4: Zeta potential of DOPC liposomes, encapsulating (5)6-carboxyfluorescein $50 \mathrm{mM}$, in $\mathbf{P B S}+\mathrm{Mg}^{2+} 5 \mathrm{mM}$ after $120 \mathrm{s.mL}{ }^{-1}$ plasma treatments and after addition of $10 \%(\mathrm{v} / \mathrm{v})$ ethanol

The fluorescence intensity of 5(6)-carboxyfluorescein, encapsulated at a concentration of $50 \mathrm{mM}$ in the DOPC liposomes, was measured after $120 \mathrm{~s} . \mathrm{mL}^{-1}$ plasma treatments and normalized against untreated samples. It has to be noted that the fluorescence intensity of non-treated samples (i.e. stock control) is already low due to the self-quenching phenomenon of the fluorescent molecules in liposomes.

All three $120 \mathrm{~s} \cdot \mathrm{mL}^{-1}$ plasma treatments unexpectedly led to a significant decrease of the fluorescence of carboxyfluorescein (Figure 5) down to very low values (close to background). The plasma treatments generate a degradation of the fluorescent dye whatever the gas mixture used. This fluorescent probe cannot resist to our plasma conditions even when they are encapsulated in liposomes. The use of this fluorescent probes is not a good approach in our case to detect the dye release from liposomes due to the novel cocktail of species generated by plasma. However, it shows that reactive species can permeate through the liposomes to react with the molecular probe inside liposomes, which is an interesting information for drug delivery or disinfection applications. 


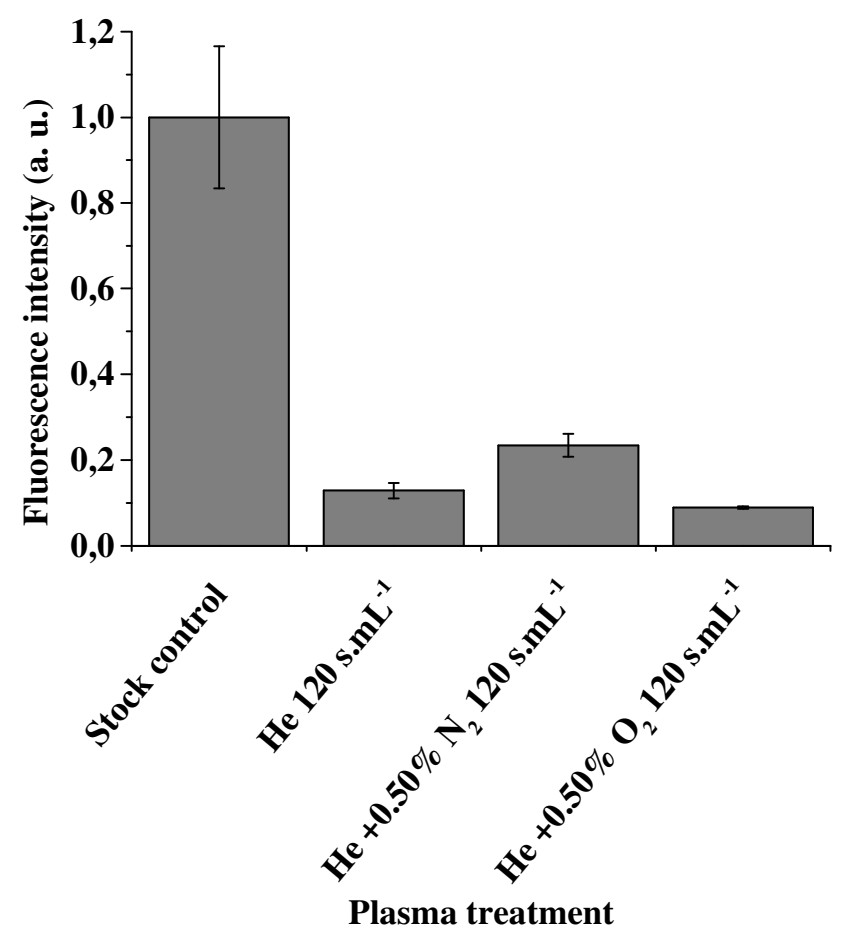

Figure 5: Normalized fluorescence intensity of (5)6-carboxyfluorescein $50 \mathrm{mM}$, encapsulated in DOPC liposomes suspended in PBS $+\mathrm{Mg}^{2+} 5 \mathrm{mM}$ after $120 \mathrm{~s} . \mathrm{mL}^{-1}$ plasma treatments $(\mathrm{n}=3)$

Erreur ! Source du renvoi introuvable. Figure 6 shows the fluorescence intensity, normalized against untreated samples, of a (5)6-carboxyfluorescein $200 \mu \mathrm{M}$ solution (not encapsulated in liposomes) in PBS + $\mathrm{Mg}^{2+} 5 \mathrm{mM}$ after $0-120 \mathrm{~s} . \mathrm{mL}^{-1} \mathrm{He}, \mathrm{He}+0.50 \% \mathrm{~N}_{2}$ and $\mathrm{He}+0.50 \% \mathrm{O}_{2}$ plasma treatments. The fluorescence decrease of non-encapsulated 5(6)-carboxyfluorescein due to the fluorescent molecule degradation is observed for all the plasma treatments even if it is less pronounced for the oxygen-containing one.

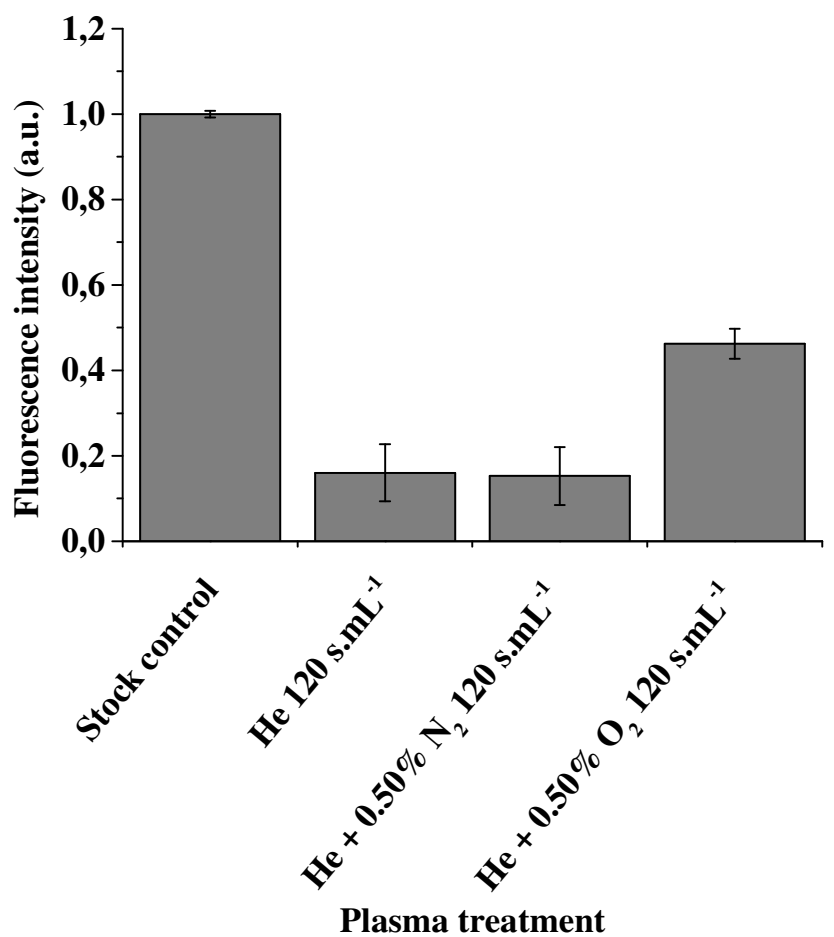


Figure 6: Normalized fluorescence intensity of (5)6-carboxyfluorescein $200 \mu \mathrm{M}$ in PBS $+\mathrm{Mg}^{2+} 5 \mathrm{mM}$ after 120 s.mL ${ }^{-1}$ plasma treatments showing the degradation of dye (i.e. bleaching) by plasma reactive species.

In order to identify which kind of plasma-generated RONS are involved in the degradation of both liposomes and fluorescent dye, we have investigated the degradation of liposomes after $35 \mathrm{~min}$ exposure to $\mathrm{HOCl}(5-$ $500 \mu \mathrm{M}), \mathrm{NH}_{2} \mathrm{Cl}(5-500 \mu \mathrm{M}), \mathrm{H}_{2} \mathrm{O}_{2}(500-5000 \mu \mathrm{M}), \mathrm{NH}_{4}{ }^{+}(500 \mu \mathrm{M}), \mathrm{NO}_{2}^{-}(500 \mu \mathrm{M}), \mathrm{NO}_{2} \mathrm{Cl}(500 \mu \mathrm{M})$ and $\mathrm{ONOO}^{-}(500 \mu \mathrm{M})$ as shown on Figure 7. These concentration ranges correspond to the quantities generated by the plasma treatments.

From all those species, only $\mathrm{HOCl}$ was able to induce an effect on 5(6)-carboxyfluorescein-loaded DOPC liposomes: the fluorescence intensity decreased to $31(\mathrm{HOCl} 5 \mu \mathrm{M})$ and $6 \%(\mathrm{HOCl} 50$ and $500 \mu \mathrm{M})$ of the original value. Although $\mathrm{NH}_{2} \mathrm{Cl}$ is potent enough to inactivate E. coli bacteria (5.2 $\log _{10}$ reduction after 35 min exposure to $45.2 \mu \mathrm{M}$ ) [13], its degradation power (i.e. fluorescence intensity decrease) on carboxyfluoreceine seemed negligible up to $500 \mu \mathrm{M}$, which is a much higher amount that the one generated by our plasma treatment (at least 10 times lower). The same observation was made for $\mathrm{NH}_{4}{ }^{+}, \mathrm{NO}_{2}{ }^{-}, \mathrm{NO}_{2} \mathrm{Cl}$ and $\mathrm{ONOO}^{-}$up to $500 \mu \mathrm{M}$ and for $\mathrm{H}_{2} \mathrm{O}_{2}$ up to $5000 \mu \mathrm{M}$ [19-22].

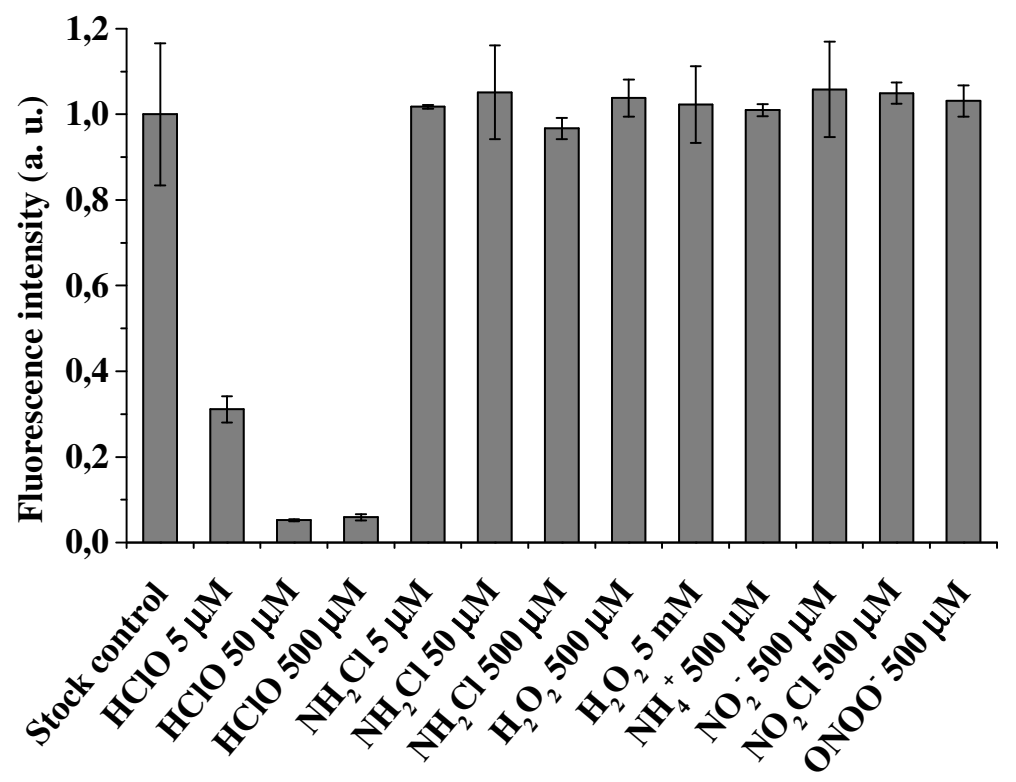

Wet chemistry treatment

Figure 7: Normalized fluorescence intensity of (5)6-carboxyfluorescein $50 \mathrm{mM}$, encapsulated in DOPC liposomes suspended in PBS + $\mathrm{Mg}^{2+} 5 \mathrm{mM}$ after 35 min chemical treatments $(\mathrm{n}=2)$

In order to determine more precisely the chemical modifications induced on the phospholipids by the plasma and chemical treatments, we used atmospheric pressure matrix-assisted laser desorption/ionization (APMALDI) mass spectrometry to identify the degradation products of DOPC. After a $\mathrm{He}+0.50 \% \mathrm{~N}_{2}$ plasma treatment of $120 \mathrm{~s} . \mathrm{mL}^{-1}$ (Figure 7), the most potent bactericidal treatment with our set of parameters, the oxidation and the formation of chlorohydrin by electrophilic addition of $\mathrm{HOCl}$ on DOPC unsaturated $\mathrm{C}=\mathrm{C}$ bonds (Figure 8) was observed [23, 24]. The direct contribution of nitrating species (e.g. peroxynitrite) is negligible, as no $\mathrm{NO}$ nor $\mathrm{NO}_{2}$ functionalization was observed on the phospholipids. This last result shows that $\mathrm{HOCl}$ is not only involved in fluorescent dye bleaching but it is also involved in the liposome membrane chemical modification, in addition to other reactive oxygen species. 


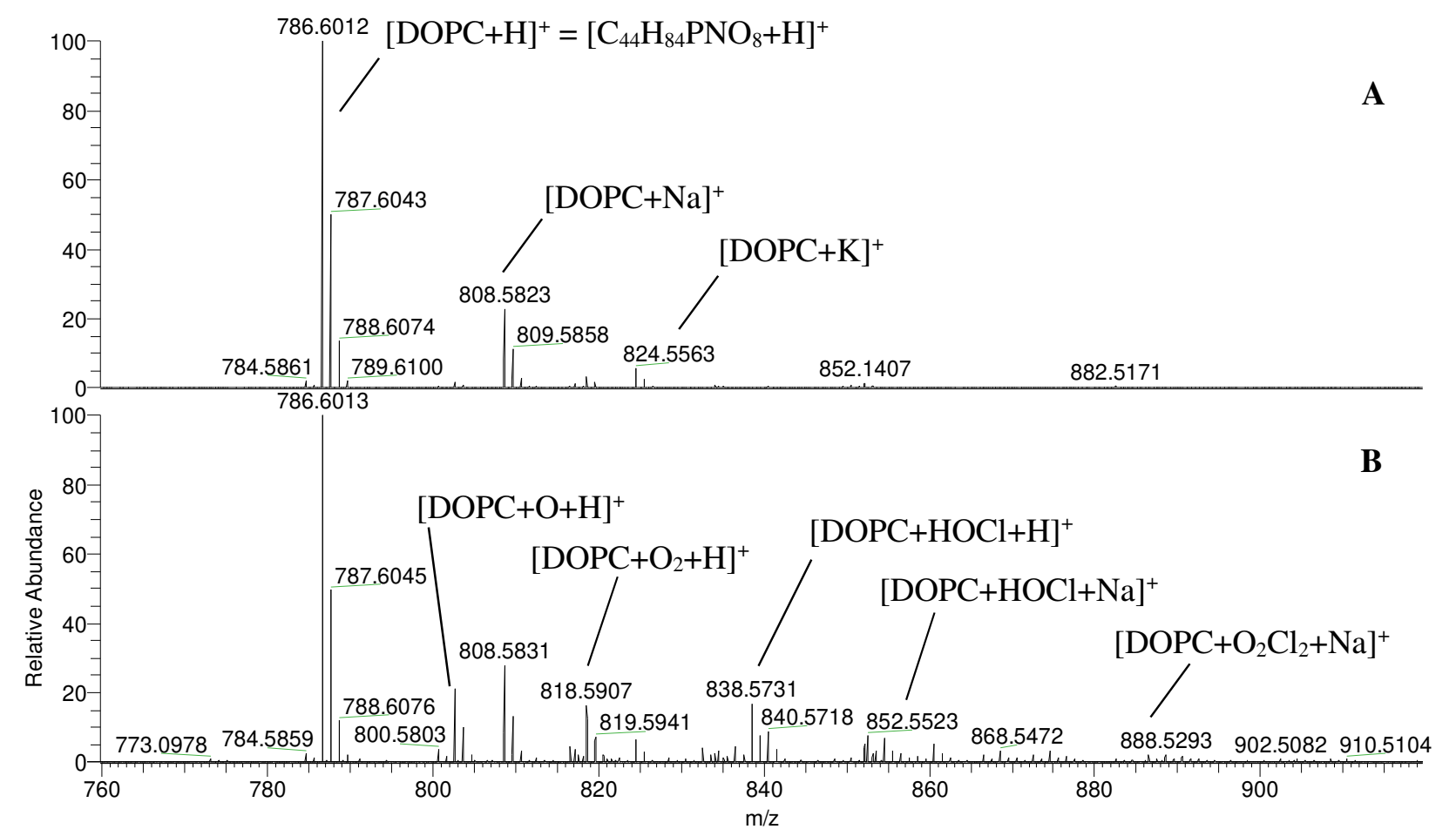

Figure 7: Positive ion AP-MALDI-Orbitrap mass spectra of DOPC liposomes in PBS $+\mathrm{Mg}^{2+} \mathbf{5 m M}$ before (A) and after $\mathrm{He}+0.50 \% \mathrm{~N}_{2} 120 \mathrm{~s} . \mathrm{mL}^{-1}$ plasma treatment $(\mathrm{B})$.
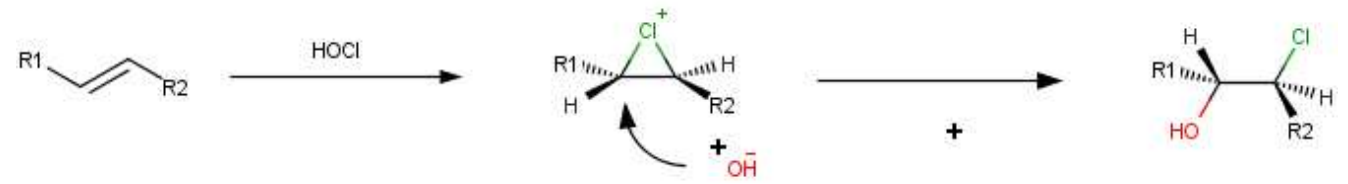

Figure 8: Formation of chlorohydrin by electrophilic addition of $\mathrm{HOCl}$ on DOPC unsaturated C=C bonds. R1 and R1 stand for carbon chains of fatty acid.

In order to identify the plasma-generated RONS responsible for the $\mathrm{O}, \mathrm{OH}$ and $\mathrm{Cl}$ functionalizations of DOPC lipid during $\mathrm{He}+0.50 \% \mathrm{~N}_{2}$ plasma treatment, AP-MALDI mass spectra of DOPC liposome suspension in PBS $+5 \mathrm{mM} \mathrm{Mg}^{2+}$ were carried out after 35 min exposure to $\mathrm{HOCl}(5-500 \mu \mathrm{M}), \mathrm{H}_{2} \mathrm{O}_{2}(500-$ $5000 \mu \mathrm{M}), \mathrm{NH}_{4}^{+}(500 \mu \mathrm{M}), \mathrm{NO}_{2}^{-}(500 \mu \mathrm{M}), \mathrm{NO}_{3}^{-}(500 \mu \mathrm{M})$ and $\mathrm{HOCl} / \mathrm{H}_{2} \mathrm{O}_{2}$ mixture $(500 \mu \mathrm{M})$ as previously done with fluorescence measurements. Figure 9 shows the positive ion AP-MALDI mass spectra of DOPC liposome suspension in PBS $+5 \mathrm{mM} \mathrm{Mg}^{2+}$ before and after exposure to $\mathrm{HOCl}$. The degradation products detected match closely those observed after $\mathrm{He}+0.50 \% \mathrm{~N}_{2} 120 \mathrm{~s}^{\mathrm{mL}} \mathrm{mL}^{-1}$ plasma treatments: DOPC phospholipids mostly underwent one to two electrophilic additions of $\mathrm{HOCl}$ molecules, when it was in contact with $\mathrm{HOCl}$ solutions. 


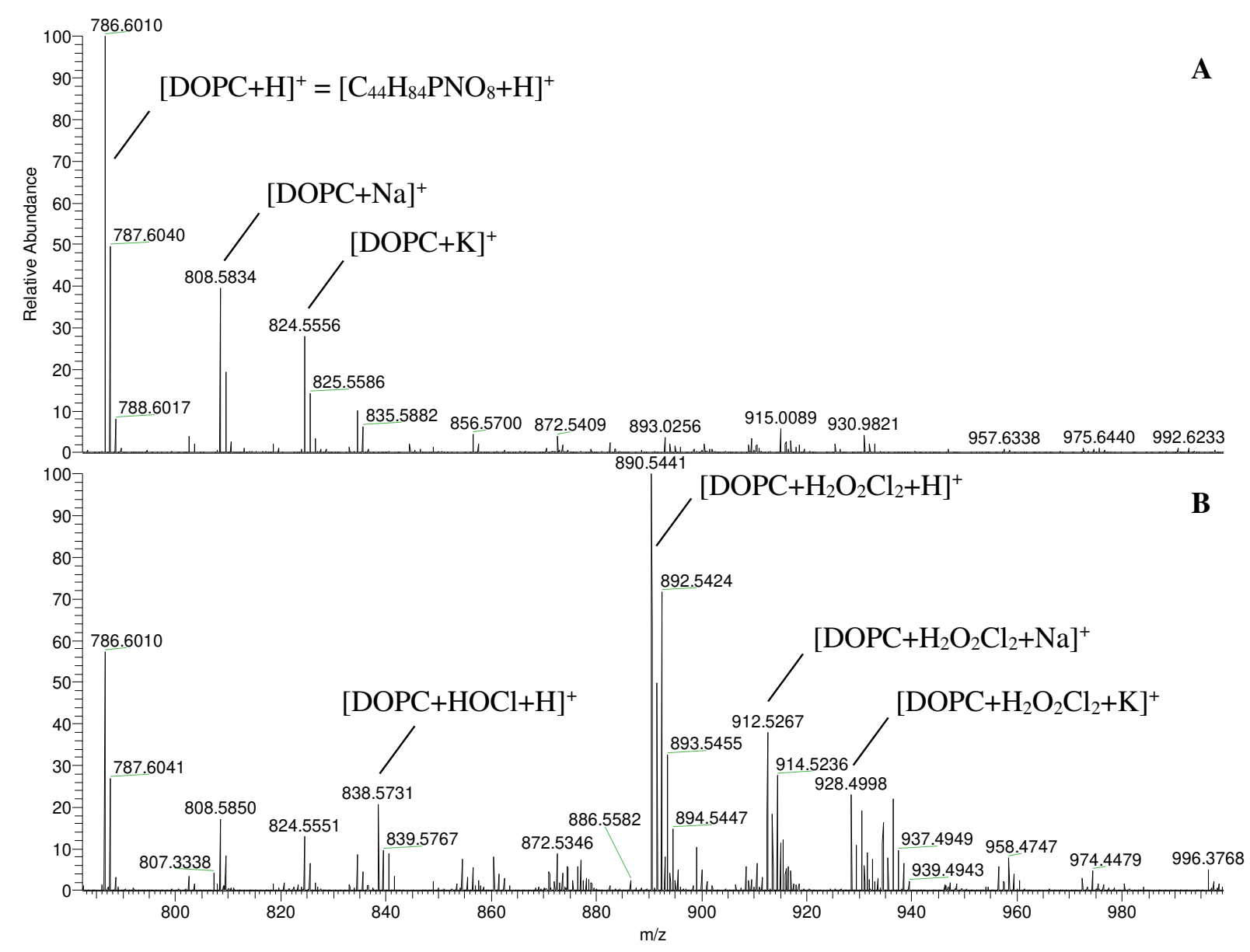

Figure 9: Positive ion AP-MALDI-Orbitrap mass spectra of DOPC liposomes in PBS $+\mathrm{Mg}^{2+} 5 \mathrm{mM}$ before (A) and after HOCl wet chemistry treatment (B)

Positive ion AP-MALDI-Orbitrap mass spectra of DOPC liposome suspension in PBS $+5 \mathrm{mM} \mathrm{Mg}^{2+}$ after exposure to $\mathrm{H}_{2} \mathrm{O}_{2}(500-5000 \mu \mathrm{M}), \mathrm{NH}_{4}{ }^{+}(500 \mu \mathrm{M}), \mathrm{NO}_{2}{ }^{-}(500 \mu \mathrm{M}), \mathrm{NO}_{3}{ }^{-}(500 \mu \mathrm{M})$ and $\mathrm{HOCl} / \mathrm{H}_{2} \mathrm{O}_{2}$ mixture $(500 \mu \mathrm{M})$ did not show any degradation of DOPC phospholipids. In the case of exposure to a $\mathrm{HOCl} /$ $\mathrm{H}_{2} \mathrm{O}_{2}$ mixture $(500 \mu \mathrm{M})$, oxidation products due to the addition of 3 to 6 oxygen atoms to DOPC phospholipids were detected. These oxidation products were not found after $\mathrm{He}+0.50 \% \mathrm{~N}_{2} 120 \mathrm{~s} . \mathrm{mL}^{-1}$ plasma treatments. In conclusion, AP-MALDI-Orbitrap measurements show that HOCl-containing solutions give the closest results to the $\mathrm{He}+0.50 \% \mathrm{~N}_{2}$ plasma treated ones in term of chemical modification on the DOPC structure.

\section{4- Discussion:}

In our conditions where a nanosecond pulsed discharge, a solution buffered to neutral $\mathrm{pH}$ and an atmosphere of pure $\mathrm{N}_{2}$ are used, energy/density of electrons and reactive species generated is high, we have observed original cocktails of reactive species formed in solution (Table 1). $\mathrm{HOCl}$ and $\mathrm{NO}_{2}{ }^{-}$are generated in higher quantities compared with more conventional discharges, except for $\mathrm{He}+\mathrm{O}_{2}$ plasma treatments. In the specific case of $\mathrm{He}+0.50 \% \mathrm{~N}_{2}$ plasma treatments, $\mathrm{NH}_{4}{ }^{+}$are also generated in significant quantity leading to the formation of $\mathrm{NH}_{2} \mathrm{Cl}$ through its reaction with $\mathrm{HOCl}$, which is favoured at neutral $\mathrm{pH}$. These novel cocktails of reactive species generated in $\mathrm{pH}$ buffered saline solutions are generating novel degradation processes both on bacteria [13], liposomes and fluorescent probes as discussed below.

a- Impact of CAP treatments on the structure and zeta potential of liposomes 
The amount of chemical modifications on the phospholipids, induced by the reactive species generated by plasma, is proportional to the density of negative charges present at the surface of liposomes. Negative charges are generated on the liposomes mainly due to the nature of chemical groups added on the unsaturations of phospholipid tail i.e. $\mathrm{OH}$ and $\mathrm{Cl}$ (Figure 8 and 9). $\mathrm{NO}_{\mathrm{x}}{ }^{-}$anions generated in large amount in solution by plasma treatment (Table 1) may also be trapped in the liposomal membrane and participate to the decrease of zeta potential. The higher amount of chemical modifications on phospholipids induced by $\mathrm{He}+$ $0.50 \% \mathrm{~N}_{2}$ plasma treatments favour the fusion of liposomes to form larger liposomes, probably due to a higher fluidity and reactivity of the plasma modified liposomal membranes. The lower degradation of liposomes after the He plasma treatments due to the lower amount of reactive species generated in solution, compared with $\mathrm{He}+0.50 \% \mathrm{~N}_{2}$ plasma (Table 1), are leading to the aggregation of the liposomes. It is thought that the fluidity/reactivity of liposomes is not increased enough in this case to lead to a fusion process. These results may be correlated with our previous results on bacteria inactivation by plasma, where He plasma treatments have almost no effect but $\mathrm{He}+0.50 \% \mathrm{~N}_{2}$ ones show a fast and intense bacterial inactivation [13]. In the case of $\mathrm{He}+0.50 \% \mathrm{O}_{2}$ plasma treatments, no significant modification of the liposomes (i.e. phospholipids) is observed. This results also correlates well with our previous bacterial inactivation results [13]. In summary, critical amounts of reactive species are necessary to lead to the aggregation and then the fusion of liposomes, which are reached only by the He plasma treatment in the first case and by the $\mathrm{He}+0.50 \% \mathrm{~N}_{2}$ in the second case. The generation of high quantities of $\mathrm{NO}_{\mathrm{x}}{ }^{-}(>6 \mathrm{mM})$ and the presence of $\mathrm{HClO}(>4 \mu \mathrm{M}), \mathrm{NH}_{4}{ }^{+}$and $\mathrm{NH}_{2} \mathrm{Cl}$ species are responsible for the coalescence of liposomes. The generation of intermediate quantities of $\mathrm{NO}_{\mathrm{x}}{ }^{-}(>3 \mathrm{mM})$ and the presence of $\mathrm{HClO}(>4 \mu \mathrm{M})$ species are responsible for the aggregation of liposomes. The generation of lower quantities of $\mathrm{NO}_{\mathrm{x}}{ }^{-}(<2 \mathrm{mM})$ and $\mathrm{HClO}(<2 \mu \mathrm{M})$ does not lead to structural modifications of liposomes.

b- Molecular mechanisms involved in the degradation processes of liposomes and fluorescent molecules:

Hypochlorites (like peroxynitrite) are typical reactive species produced in the organism under pathological conditions or during plasma treatment of water solutions and having a large range of biological effects such as erythrocyte oxidative damage [25]. $\mathrm{HClO}$ can penetrate into cells and be transformed through a nonenzymatic reaction into other $\mathrm{ROS}$ (e.g. $\mathrm{OH}$ and ${ }_{1} \mathrm{O}^{2}$ ) [26] to generate local oxidation processes. The degradation effects of $\mathrm{HClO}$ are also explained by the formation of chloramines due to their reactions with the amino group of lipids or proteins [27, 28,] and also by the formation of chlorohydrins (Figure 9) [23, 24]. Cell exposure to $\mathrm{HClO}$ was shown to lead to structural rearrangement of the membrane, cell swelling and pore formation $[27,28]$.

When using a plasma touching saline water solutions, $\mathrm{HClO}$ can be generated by the reaction between $\mathrm{OH}$ radicals generated by plasma reactive species in contact with water and $\mathrm{Cl}^{-}$ions present in our solution at a concentration of $154 \mathrm{mM}$. In our specific conditions, it is shown that $\mathrm{HOCl}$ seems to play a major role in fluorescent dye and liposome degradations even at very low concentration of a few $\mu \mathrm{M}$. For the liposome degradation, the formation of chlorohydrin by electrophilic addition of $\mathrm{HOCl}$ on $\mathrm{DOPC}$ unsaturated $\mathrm{C}=\mathrm{C}$ bonds is one reaction pathway as shown from our high resolution mass spectrometry results (Figure 8 and 9) $[23,24]$. The generation of ROS in the vicinity of phospholipids from $\mathrm{HOCl}$ degradation [26] can also lead to oxidation processes mainly on the $\mathrm{C}=\mathrm{C}$ unsaturated bond of the phospholipid tail as shown on Figure 8 with peaks at 802.6 ( $\mathrm{O}$ addition), 818.6 ( $2 \mathrm{O}$ additions) and $888.5\left(2 \mathrm{O}+2 \mathrm{Cl}_{2}\right.$ additions). The formation of chloramine from the reaction of $\mathrm{HOCl}$ with amine of the phospholipid head was not observed probably due to the low reactivity of the tertiary amine for DOPC. Concerning the (5)6-carboxyfluorescein, the molecule is degraded whatever the plasma treatment and whatever if encapsulated or not. $\mathrm{HClO}$ seem to be the main reactive species involved in the degradation of the fluorescent probe (Figure 7), which explain why $\mathrm{He}+$ $0.50 \% \mathrm{O}_{2}$ plasma treatments induces less (5)6-carboxyfluorescein degradation and the other plasma treatments higher and similar rates of degradation (figure 6) because $\mathrm{HOCl}$ concentrations generated are similar (Table 1). Bleaching of fluorescein by oxygen molecules and ROS has already been reported under light irradiation [29] but the conditions and degradation processes are different to the ones studied in this 
work. In particular, no significant amount of photons are generated at the vicinity of dye molecules in our case. The (5)6-carboxyfluorescein plasma degradation processes observed here, probably by $\mathrm{HOCl}$ species, have been better documented in [30]. The (5)6-carboxyfluorescein degradation by $\mathrm{HOCl}$, can be either due to an electrophilic addition of $\mathrm{HOCl}$ on an aromatic $\mathrm{C}-\mathrm{C}$ bond or an oxidation of $\mathrm{C}-\mathrm{C}$ aromatic bonds, both processes leading to $\mathrm{C}-\mathrm{C}$ aromatic bond breaking. Future mass spectrometry measurements will allow us to determine the degradation process in our conditions.

$\mathrm{NO}_{2}^{-}$are known to generate oxidation processes through the formation of reactive oxygen intermediates, which can attack biomolecules present in their vicinity and can lead to lipid peroxidation, protein modification, DNA damage, etc. However, it is shown in our case that nitrite ions are not generating as much damage as expected (e.g. case of He plasma treatments). This last observation can be partly explained by our neutral $\mathrm{pH}$ conditions, which inhibit the formation of $\mathrm{NO}_{2} \mathrm{H}$ and $\mathrm{NO}_{2}$ intermediate species from $\mathrm{NO}_{2}{ }^{-}$species and therefore inhibit the addition of $\mathrm{NO}_{2}$ on the $\mathrm{C}$ in $\alpha$ position of the $\mathrm{C}=\mathrm{C}$ unsaturated bond in the phospholipid tail as explained by Mendiara et al. [31]. The lack of molecular fragments with an $\mathrm{NO}_{2}$ addition confirmed this hypothesis (Figure 8). However, a part of oxidation processes observed on Figure 8 (already mentioned as a possible $\mathrm{HOCl}$ effect above) can be generated indirectly by nitrite ions, which explain why $\mathrm{He}+0.50 \% \mathrm{O}_{2}$ plasma treatments are generating higher degradation effects on liposomes. These oxidations processes can also be involved in the (5)6-carboxyfluorescein degradation.

Finally, effects of $\mathrm{NH}_{2} \mathrm{Cl}$ and $\mathrm{NH}_{4}{ }^{+}$species, only produced by $\mathrm{He}+0.50 \% \mathrm{~N}_{2}$ plasma treatments, on liposomes and (5)6-carboxyfluorescein degradation are more difficult to discuss because they are masked by the effect of nitrite ions generated in much higher quantities for $\mathrm{He}+0.50 \% \mathrm{~N}_{2}$ plasma treatments. There is also no pertinent work describing their possible role in the degradation of liposomes and dye molecule similar to (5)6-carboxyfluorescein. More experiments will be carried out to determine their role in the degradation processes.

\section{Conclusion}

In this work, where novel cocktails of reactive species are generated by cold atmospheric plasma in $\mathrm{pH}$ buffered aqueous solution containing liposomes loaded with a fluorescent dye, it has been shown that several and novel plasma degradation mechanisms of DOPC small unilameller liposomes and carboxyfluoresceine dye are generated in suspensions touched by the plasma. $\mathrm{HOCl}$ generated in the micromolar range combined with nitrite ions generated in the $\mathrm{mM}$ range is mainly responsible of the degradation of the carboxyfluoresceine dye molecules, which make the use of this fluorescent probe not so pertinent in these conditions. It is probable that no fluorescent dye can resist to these plasma treatments and another method than fluorescence spectroscopy is needed to follow the permeation of molecular probe through the liposomal membrane. When a critical quantity of reactive species (i.e. $\mathrm{HOCl}, \mathrm{NO}_{2}{ }^{-}$and other $\mathrm{ROS}$ generated locally from $\mathrm{HOCl}$ and $\mathrm{NO}_{2}^{-}$) generated by the plasma in the suspension is reached, the aggregation of liposomes and the increase of negative charges on liposomes is observed (case of $\mathrm{He}+0.50 \% \mathrm{O}_{2}$ plasma treatments). When another higher critical quantity of reactive species (i.e. $\mathrm{HOCl}, \mathrm{NO}_{2}^{-}, \mathrm{NH}_{4}{ }^{+}, \mathrm{NH}_{2} \mathrm{Cl}$ and $\mathrm{ROS}$ ) generated by plasma in the suspension is reached, the fusion of liposomes, an higher increase of negative charges of liposomes and the leakage of fluorescent dye from liposomes is observed (case of $\mathrm{He}+0.50 \% \mathrm{O}_{2}$ plasma treatments). Reactive species are shown to react with the liposomal membranes through $\mathrm{HOCl}$ electrophilic addition and oxidation processes mainly on the unsaturated $\mathrm{C}=\mathrm{C}$ bond of the phospholipid tail. These chemical modifications make liposomes more permeable leading to the permeation of encapsulated dye through the membrane, and also more reactive and more flexible leading to a point where liposome fusion is observed. The reactive species (e.g. $\mathrm{HOCl}, \mathrm{NO}_{2}{ }^{-}$) generated by plasma are also able to cross the liposomal membrane to react with the fluorescent molecules inside the liposomes without the failure of the liposomes. This work bring novel information about degradation processes of encapsulated fluorescent molecules and model membranes that can partially explain previous results on bacterial disinfection in similar conditions [13]. These results will be also very useful for future studies dealing with the selectivity of plasma treatments 
for therapeutic applications and the association of plasma treatments and nanomedicine for novel therapeutic and diagnostic applications.

\section{Acknowledgments}

The authors would like to acknowledge, from LIST, M. Gerard and O. Bouton for technical support, M. Hammer from INP Greifswald for liposome preparation and members of COST action TD1208 for supporting discussions. This work was partially supported by the Fonds National de la Recherche du Luxembourg and by the European Laboratory LEA-LIPE.

\section{References}

[1] von Woedtke T, Reuter S, Masur K and Weltmann K-D 2013 Plasmas for medicine Phys. Rep. 530 291-320

[2] McDonnell G and Russell A D 1999 Antiseptics and disinfectants: activity, action, and resistance. Clin. Microbiol. Rev. 12 147-79

[3] Kong M G, Kroesen G, Morfill G, Nosenko T, Shimizu T, van Dijk J and Zimmermann J L 2009 Plasma medicine: an introductory review New J. Phys. 11115012

[4] Roth J R 2005 Potential industrial applications of the one atmosphere uniform glow discharge plasma operating in ambient air Phys. Plasmas 12057103

[5] Attri P, Arora B and Choi E H 2013 Utility of plasma: a new road from physics to chemistry RSC Adv. 3 12540-67

[6] Naïtali M, Kamgang G, Herry J-M, Bellon-Fontaine M-N and Brisset J-L 2010 Combined effects of long-living chemical species during microbial inactivation using atmospheric plasma-treated water. Appl. Environ. Microbiol. 76 7662-4

[7] Oehmigen K, Winter J, Hähnel M, Wilke C, Brandenburg R, Weltmann K-D and von Woedtke T 2011 Estimation of Possible Mechanisms of Escherichia coli Inactivation by Plasma Treated Sodium Chloride Solution Plasma Process. Polym. 8 904-13

[8] Pavlovich M J, Chang H-W, Sakiyama Y, Clark D S and Graves D B 2013 Ozone correlates with antibacterial effects from indirect air dielectric barrier discharge treatment of water J. Phys. D. Appl. Phys. 46145202

[9] Baik K Y, Kim Y H, Ryu Y H, Kwon H S, Park G, Uhm H S and Choi E H 2013 Feeding-Gas Effects of Plasma Jets on Escherichia coli in Physiological Solutions Plasma Process. Polym. 10 $235-42$

[10] Liu F, Sun P, Bai N, Tian Y, Zhou H, Wei S, Zhou Y, Zhang J, Zhu W, Becker K and Fang J 2010 Inactivation of Bacteria in an Aqueous Environment by a Direct-Current, Cold-Atmospheric-Pressure Air Plasma Microjet Plasma Process. Polym. 7 231-6

[11] Lukeš P, Dolezalova E, Sisrova I and Clupek M 2014 Aqueous-phase chemistry and bactericidal effects from an air discharge plasma in contact with water: evidence for the formation of peroxynitrite through a pseudo-second-order post-discharge reaction of H 2 O 2 and HNO 2 Plasma Sources Sci. Technol. 23015019

[12] Machala Z, Tarabova B, Hensel K, Spetlikova E, Sikurova L and Lukeš P 2013 Formation of ROS and RNS in Water Electro-Sprayed through Transient Spark Discharge in Air and their Bactericidal Effects Plasma Process. Polym. 10 649-59 
[13] Maheux S, Duday D, Belmonte T, Penny C, Cauchie H-M, Clément F and Choquet P 2015 Formation of ammonium in saline solution treated by nanosecond pulsed cold atmospheric microplasma: a way to fast inactivation of E. coli bacteria $R S C A d v .542135-40$

[14] Szili, E. J., Hong, S.-H., Short, R. D., 2015. On the effect of serum on the transport of reactive oxygen species across phospholipid membranes, Biointerphases 10029511

[15] Lindén M V., Wiedmer S K, Hakala R M S and Riekkola M-L 2004 Stabilization of phosphatidylcholine coatings in capillary electrophoresis by increase in membrane rigidity $J$. Chromatogr. A 1051 61-8

[16] Svarnas P, Matrali S H, Gazeli K, Aleiferis S, Clément F and Antimisiaris S G 2012 Atmosphericpressure guided streamers for liposomal membrane disruption Appl. Phys. Lett. 101264103

[17] Chanturiya A, Leikina E, Zimmerberg J and Chernomordik L V. 1999 Short-Chain Alcohols Promote an Early Stage of Membrane Hemifusion Biophys. J. 77 2035-45

[18] Blicher A, Wodzinska K, Fidorra M, Winterhalter M and Heimburg T 2009 The Temperature Dependence of Lipid Membrane Permeability, its Quantized Nature, and the Influence of Anesthetics Biophys. J. 96 4581-91

[19] Sadowska-Bartosz I, Adamczyk R and Bartosz G 2014 Protection against peroxynitrite reactions by flavonoids Food Chem. 164 228-33

[20] Nicolescu A C, Zavorin S I, Turro N J, Reynolds J N and Thatcher G R J 2002 Inhibition of Lipid Peroxidation in Synaptosomes and Liposomes by Nitrates and Nitrites Chem. Res. Toxicol. 15 985-98

[21] Beutler M, Heisterkamp I M, Piltz B, Stief P and De Beer D 2014 Microscopic oxygen imaging based on fluorescein bleaching efficiency measurements Microsc. Res. Tech. 77 341-7

[22] Kettle A J, Albrett A M, Chapman A L, Dickerhof N, Forbes L V., Khalilova I and Turner R 2014 Measuring chlorine bleach in biology and medicine Biochim. Biophys. Acta 1840 781-93

[23] Spickett C M, Jerlich A, Panasenko O M, Arnhold J, Pitt A R, Stelmaszyńska T and Schaur R J 2000 The reactions of hypochlorous acid, the reactive oxygen species produced by myeloperoxidase, with lipids. Acta Biochim. Pol. 47 889-99

[24] Robaszkiewicz, A., Greig, F.H., Pitt, A.R., Spickett, C.M., Bartosz, G. and Soszynski, M. Effect of phosphatidylcholine chlorohydrins on human erythrocytes. Chem. Phys. Lipids 163 (2010) 639-647

[25] E. Olchowik, K. Lotkowski, S. Mavlyanov, N. Abdullajanova, M. Ionov, Bryszewska, et al. Stabilization of erythrocytes against oxidative and hypotonic stress by tannins isolated from Sumac leaves (Rhus typhina L.) and grape seeds (Vitis vinifera L.) Cellular \& Molecular Biology Letters, 17 (2012), pp. 333-348

[26] Pennathur, S., Maitra, D., Byun, J., Slikovic, I., Abdulhamid, I., Saed, G.M., Diamond, M.P. and Abu-Soud, H.M. Potent antioxidative activity of lycopene: A potential role in scavenging hypochlorous acid. Free Radic.Biol. Med. 49 (2010) 205-213

[27] Zavodnik, L.B., Zavodnik, I.B., Lapshyna E.A., Buko, V.U. and Bryszewska, M.J. Hypochlorous acid-induced membrane pore formation in red blood cells. Bioelectrochemistry 58 (2002) 157-161.

[28] Zavodnik, I.B., Lapshina, E.A., Zavodnik, L.B., Bartosz, G., Soszynski, M. and Bryszewska, M. Hypochlorous acid damages erythrocyte membrane proteins and alters lipid bilayer structure and fluidity. Free Radic. Biol. Med. 30 (2001) 363-369.

[29] Song L, Hennink E J, Ted Young I, Tanke H J 1995 Photobleaching kinetics of fluorescein in quantitative fluorescence microscopy. Biophys. J., 68 2588-2600

[30] Q.A. Best, N. Sattenapally, D.J. Dyer, C.N. Scott, M.E. McCarroll, pH-Dependent Si-Fluorescein Hypochlorous Acid Fluorescent Probe:Spirocycle Ring-Opening and Excess Hypochlorous Acid- 
Induced Chlorination, J. Am. Chem. Soc., 135 (2013) 13365-13370

[31] Mendiara, S. N.; Baquero, R. P.; Katunar, M. R.; Mansilla, A. Y.;Perissinotti, L. J. Reaction of $\beta$ carotene with nitrite anion in a homogeneous acid system. An electron paramagnetic resonance and ultraviolet-visible study, Appl. Magn. Reson. 2009,35, 549-567 